\title{
The Effects of Rootstocks and Training Systems on the Early Performance of '0900 Ziraat' Sweet Cherry
}

\author{
Erdal AGLAR ${ }^{1 *}$, Kenan YILDIZ ${ }^{2}$, Lynn Edwards LONG $^{3}$ \\ ${ }^{1}$ Cumburiyet University, Suşehri Timur Karabal Vocational School, 58602 Sivas, Turkey; erdalaglar@gmail.com (*correspondence author) \\ ${ }^{2}$ Gaziosmanpaşa University, Department of Horticulture, Faculty of Agriculture, 60240 Tokat, Turkey; kenan.yildiz@gop.edu.tr \\ ${ }^{3}$ Oregon State University, 400 E Scenic Dr Suite 2.278. The Dalles, OR 97058, USA; lynn.long@oregonstate.edu
}

\begin{abstract}
The effects of three rootstocks ('Gisela 5', 'Gisela 6' and 'MaxMa 14') and three training systems (Spanish bush, Steep leader and Vogel central leader) on early performance of ' 0900 Ziraat' sweet cherry were compared. There have been significant differences among both rootstocks and training systems in terms of tree heights. At the end of the fourth year, while the height of the trees grafted on 'Gisela 5' was $238.3 \mathrm{~cm}$, those grafted on 'MaxMa 14' reached $266.4 \mathrm{~cm}$ in height. While the shortest tree height was obtained from Spanish bush system, heights of the trees in Steep leader and Vogel central leader training systems were found to be at similar levels. 'Gisela' 5 had lower trunk cross section area (TCSA) than 'Gisela 6 ' and 'MaxMa 14' rootstocks. Among three systems, trees trained to Steep leader had the highest TCSA, followed by Spanish bush and Vogel central leader. Interactions were found between rootstock and training system for yield and yield efficiency. On 'Gisela 6', cumulative yield of Vogel central leader system ( $17.0 \mathrm{~g} /$ tree $)$ was significantly higher than Spanish bush ( $14.8 \mathrm{~g} / \mathrm{tree})$ and Steep leader (12.6 g/tree). On the other hand, on 'MaxMa 14', there were not significant differences in cumulative yield per tree among training systems. On 'Gisela 5' and 'Gisela 6', the highest yield efficiency were observed in trees trained as Vogel central leader. Yield efficiency of Vogel central leader $\left(0.49 \mathrm{~kg} \mathrm{~cm}^{-2}\right)$ was two time higher than those of Spanish bush $(0.29 \mathrm{~kg}$ $\left.\mathrm{cm}^{-2}\right)$ and Steep leader $\left(0.26 \mathrm{~kg} \mathrm{~cm}^{-2}\right)$ on 'Gisela 6'. The weight of fruits from trees grafted on 'Gisela 5' was lower than those from trees on 'Gisela 6 ' and 'MaxMa 14'. In the fourth year, while the average fruit weight was $5.86 \mathrm{~g}$ on 'Gisela 5', it was 6.00 and $6.25 \mathrm{~g}$ on 'Gisela 6' and 'MaxMa 14' rootstocks respectively.
\end{abstract}

Keywords: high density, Prunus avium, tree vigour, trunk cross-sectional area (TCSA), yield efficiency

\section{Introduction}

Turkey is the first in the world cherry production by meeting $21 \%$ of total production in the world (Anonymous, 2014). The most commonly used cherry rootstocks in Turkey are Prunus mahaleb and Prunus avium. The training systems that are practiced on the trees grafted on these vigorous rootstocks are generally modified leader or multiple leader systems (Başkaya, 2011). These production systems lack precocity and first fruits are harvested in the $5^{\text {th }}$ or $6^{\text {th }}$ year and full production is not reached until $10-12^{\text {th }}$ years. This is an undesirable situation for growers, since the return on investment from establishing the orchard is delayed (Whiting et al., 2005). Also, since the grafted trees on these rootstocks are vigorous, costs of harvest and pruning becomes higher.

Economic concerns lead growers to search for methods that allow precocious and improve labour efficiency. These objectives have been accomplished by using size controlling and precocity rootstocks. Rootstocks used in sweet cherry culture directly affect the size and form of the tree, as well as precocity and yield (Fajt et al., 2009; Lanauskas et al., 2012). Moreover, they affect pruning, training system and labour decisions (Long, 2003).

'Gisela' rootstocks series, which are developed in Germany, are used more widespread over the last few years. It is reported that about one-third of new orchards in the Pacific Northwest are established using 'Gisela 5' or 'Gisela 6' (Whiting et al., 2005). It is also reported that in Macedonia, 'Gisela 5' started to replace Mahaleb and Mazzard rootstocks due to its ability to yield dwarf and precocious trees (Gjamovski et al., 2016). Whiting et al. (2005), confirm that both 'Gisela 5' and 'Gisela 6' rootstocks' yield per tree is higher than that of Mazzard. Rootstocks have important effects on fruit quality as well. In a study conducted to investigate the effects of Prunus 
574

avium, 'CAB11E', 'MaxMa 14', 'Gisela 5' and 'Tabel Edabriz' rootstocks, it is observed that the highest quality fruit is obtained from the trees grafted on 'MaxMa 14' rootstock (Gonçalves et al., 2005).

Intense planting systems implemented by using such rootstocks require more efficient training systems which induce early, regularly and high yield, and efficient harvest (Radunic et al., 2011). In recent years, the desire for high yield and efficient harvest have led to the development of many different training systems such as Steep leader, Vogel central leader, Spanish bush, Kym green bush, Upright fruiting offshoots, Tall spindle axe and the Super slender axe (Zahn, 1992; Robinson, 2005). These new training systems provide early cropping and high yield and enhance cropping efficiency and fruit quality by increasing the influx and distribution of sunlight in flower petals (Lauri and Claverie, 2005). In a study conducted with several different cherry varieties grafted on 'Gisela 6' rootstocks, Musacchi et al. (2015) state that it is possible to achieve early cropping and increase yield and fruit quality by using the appropriate training system for a variety.

Considering sweet cherry exports by countries, Turkey is in the third place after USA and Chile. The most important sweet cherry variety cultivated in Turkey is ' 0900 Ziraat'. Due to its low cracking rate and high fruit quality, '0900 Ziraat' is a favored variety in both Turkish and European markets.. Approximately $90 \%$ of Turkey's sweet cherry exports comprise of ' 0900 Ziraat' variety (Çerçinli $\ddot{O} z$ and Bal, 2016). However, it is not a self-fertile cultivar and needs pollinators in its plantings. In addition, it has low fruit set, which leads to low productivity (Mert and Soylu, 2007). Due to its high export potential, sweet cherry production is on the increase in Turkey. While as a variety '0900 Ziraat' is preferred, use of 'Gisela 5', 'Gisela 6' and 'MaxMa 14' rootstocks becomes widespread since these rootstocks enable intense planting and control tree strength. On the other hand, there is not enough knowledge and research about training systems that suit intense planting systems using these rootstocks. Taking this into consideration, in this study, the effects of some rootstocks and training systems suitable for intense planting system on '0900 Ziraat' variety's performance are investigated.

\section{Materials and Methods}

\section{Site and climatic conditions}

The study was carried out between 2010 and 2014 in Suşehri $\left(39^{\circ} 20^{\prime} 02.19^{\prime \prime} \mathrm{N}\right.$ latitude, $37^{\circ} 20^{\prime} 02.19^{\prime \prime}$ E longitude and $950 \mathrm{~m}$ altitude), a district of Sivas, Turkey. The average annual temperature in Suşehri is $10^{\circ} \mathrm{C}$. The highest temperature, in July, averages $35.9^{\circ} \mathrm{C}$; the coldest temperature, in January, averages $-16.6^{\circ} \mathrm{C}$. Annual precipitation is $420 \mathrm{~mm}$ monthly average sunshine is 209 hours. A pre-plant soil analysis indicated that orchard soil was clayey-loam; $\mathrm{pH}$ was 7.9 and the lime rate was $3 \%$.

\section{Plantmaterial}

Trees of ' 0900 Ziraat' grafted on 'Gisela 5', 'Gisela 6', or 'MaxMa 14' rootstocks were planted on $21^{\text {st }}$ March 2010. Planting spaces were $2.5 \times 4 \mathrm{~m}$ for 'Gisela 5 ' and $3 \times 4 \mathrm{~m}$ for 'Gisela 6' and 'MaxMa 14'. Trees were trained to Spanish bush, Steep leader or Vogel central leader systems. A randomized block design was used with the orchard divided into three blocks with lots of five trees for each rootstock and training system combination.

Tree height, canopy volume, TCSA, yield, cumulative yield, yield efficiency

Tree height and canopy volume were recorded every year. Canopy volume $(\mathrm{V})$ was calculated by measuring canopy height and width and using the formula $V=\pi r^{2} \cdot h / 2$. Trunk diameter was measured $15 \mathrm{~cm}$ above the graft union in the north-south and the east-west orientation, and trunk crosssectional area (TCSA) was calculated by using the average of these two values. Yield per tree in 2013 and 2014, cumulative yield per tree and yield efficiency (cumulative yield in $\mathrm{kg}$ per final TCSA) were recorded.

\section{Fruit quality evaluation}

Fruit weight was determined by using all fruit from a tree without sampling. At harvest, 20 fruits at commercial ripening stage were sampled from each tree. A sample of juice was taken from one piece of each of twenty fruits per tree. Soluble solid content was determined with a digital refractometer (PAL-1, McCormick Fruit Tech., Yakima, Wash) with using juice obtained from each replication. For titratable acidity (TA), 10 $\mathrm{ml}$ of extract was taken from each sample, $10 \mathrm{ml}$ of distilled water was added and the value corresponding to consumed sodium hydroxide $(\mathrm{NaOH})$ during the titration with $0.1 \mathrm{~N}$ $\mathrm{NaOH}$ to increase the $\mathrm{pH}$ of samples to 8.1 was expressed in malic acid (g malic acid $100 \mathrm{~mL}^{-1}$ ). Texture Analyzer, Zwick Z0.5 (Zwick/Roell Z0.5, Germany), fitted with a $1.8 \mathrm{~mm}$ penetrometer probe, operating at a penetration speed of 0.5 $\mathrm{mm} \mathrm{s}$ and a penetration depth of $5 \mathrm{~mm}$, was used to measure flesh firmness $\left(\mathrm{N} \mathrm{mm}^{-1}\right)$. Colour characteristics $\left[a^{*}, b^{*}\right.$ and hue angle $\left(b^{\circ}\right)$ ] were measured from one point over the equatorial section of fruit skin with a colorimeter (Minolta, model CR400, Tokyo, Japan). Chromatic analyses were conducted in accordance with the CIE (Commission Internationale de l'Eclairage) system of 1976. The hue angle $\left(b^{\circ}\right)$ expresses the color nuance and values are defined as follows: red-purple: $0^{\circ}$; yellow: $90^{\circ}$; bluish green: $180^{\circ}$; blue: $270^{\circ}$. The hue angle value was calculated with the formula $b^{\circ}=\tan ^{-1} b / a^{*}$.

\section{Statistical analysis}

The experiment was laid out as two-factor experiment with three rootstocks and three training systems arranged in a randomized complete block design with three replications. Data were evaluated by analysis of variance with SPSS13.0.1 (SPSS, Inc., Chicago, USA). When the F test was significant, means were separated by Duncan's Multiple Range test $(\mathrm{P} \leq$ 0.05).

\section{Results and Discussion}

During the four years of the trial, the tall of trees on 'MaxMa 14' were higher than these on 'Gisela 5' and 'Gisela 6' rootstocks. In 2011, there were not significant differences in TCSA among the rootstocks (Table 1). In 2012, TCSA of the trees grafted on 'MaxMa 14' rootstocks was larger than of those grafted on 'Gisela' rootstocks. In the subsequent years (2013 and 2014), TCSA of the trees grafted on 'Gisela 5' rootstocks was lower than the other two (Fig. 1). These results confirm that the rootstock affects tree strength significantly, and among 
Table 1. Influence of rootstock and training system on vegetative growth: tree height and TCSA

\begin{tabular}{|c|c|c|c|c|c|c|c|c|c|}
\hline \multirow{2}{*}{ Rootstock } & \multirow{2}{*}{$\begin{array}{c}\text { Training } \\
\text { system }\end{array}$} & \multicolumn{4}{|c|}{ Tree height $(\mathrm{cm})$} & \multicolumn{4}{|c|}{ TCSA $\left(\mathrm{cm}^{2}\right)$} \\
\hline & & 2011 & 2012 & 2013 & 2014 & 2011 & 2012 & 2013 & 2014 \\
\hline \multirow{3}{*}{ 'Gisela 5’ } & S.B & 176.7 & $191.0 \mathrm{a}$ & $224.3 \mathrm{a}$ & $226.7 \mathrm{~b}$ & $9.54 \mathrm{~b}$ & $18.81 \mathrm{ab}$ & 27.89 & 36.73 \\
\hline & S.L & 205.9 & $217.0 \mathrm{a}$ & $233.5 \mathrm{a}$ & $248.8 \mathrm{a}$ & $12.66 \mathrm{a}$ & $23.07 \mathrm{a}$ & 29.94 & 47.52 \\
\hline & V.C.L & 181.1 & $205.0 \mathrm{a}$ & $232.6 \mathrm{a}$ & $239.0 \mathrm{ab}$ & $9.01 \mathrm{~b}$ & $16.29 b$ & 24.71 & 31.56 \\
\hline \multirow{3}{*}{ 'Gisela 6' } & S.B & 194.5 & $217.1 \mathrm{a}$ & $232.1 \mathrm{~b}$ & $239.7 \mathrm{a}$ & $11.26 \mathrm{a}$ & $20.15 \mathrm{a}$ & 31.37 & 50.45 \\
\hline & S.L & 187.5 & $212.1 \mathrm{a}$ & $226.5 b$ & $253.2 \mathrm{a}$ & $11.67 \mathrm{a}$ & $20.24 \mathrm{a}$ & 30.99 & 47.52 \\
\hline & V.C.L & 187.4 & $220.1 \mathrm{a}$ & $266.1 \mathrm{a}$ & $258.7 \mathrm{a}$ & $9.58 \mathrm{a}$ & $17.56 \mathrm{a}$ & 31.61 & 36.94 \\
\hline \multirow{3}{*}{ 'MaxMa 14' } & S.B & 218.1 & $248.7 \mathrm{a}$ & $278.5 \mathrm{~b}$ & $263.7 \mathrm{a}$ & $10.22 \mathrm{ab}$ & $20.40 \mathrm{~b}$ & 33.61 & 46.77 \\
\hline & S.L & 237.6 & $266.6 \mathrm{a}$ & 299.8 a & $261.7 \mathrm{a}$ & $12.86 \mathrm{a}$ & $27.81 \mathrm{a}$ & 38.14 & 54.35 \\
\hline & V.C.L & 215.3 & $257.2 \mathrm{a}$ & $275.6 \mathrm{~b}$ & $273.8 \mathrm{a}$ & $9.85 \mathrm{~b}$ & $21.59 \mathrm{~b}$ & 33.11 & 47.78 \\
\hline Rootstock & & \multicolumn{8}{|c|}{ Rootstock average } \\
\hline \multicolumn{2}{|l|}{ 'Gisela 5' } & $187.9 \mathrm{~b}$ & $204.3 \mathrm{~b}$ & $230.1 \mathrm{~b}$ & $238.2 \mathrm{~b}$ & 10.41 & $19.39 \mathrm{~b}$ & $27.51 \mathrm{~b}$ & $38.60 \mathrm{~b}$ \\
\hline \multicolumn{2}{|l|}{ 'Gisela 6' } & $189.8 \mathrm{~b}$ & $216.4 \mathrm{~b}$ & $241.6 \mathrm{~b}$ & $250.5 \mathrm{~b}$ & 10.83 & $19.31 \mathrm{~b}$ & $31.32 \mathrm{a}$ & $44.97 \mathrm{a}$ \\
\hline \multicolumn{2}{|l|}{ MaxMa 14} & $223.6 \mathrm{a}$ & $257.5 \mathrm{a}$ & $284.6 \mathrm{a}$ & $266.4 \mathrm{a}$ & 10.97 & $23.26 \mathrm{a}$ & $34.95 \mathrm{a}$ & $49.63 \mathrm{a}$ \\
\hline \multicolumn{2}{|l|}{ Training System } & \multicolumn{8}{|c|}{ Training system average } \\
\hline \multicolumn{2}{|l|}{ S.B } & $196.4 \mathrm{~b}$ & $218.9 \mathrm{~b}$ & $244.9 \mathrm{~b}$ & $243.4 \mathrm{~b}$ & $10.34 \mathrm{~b}$ & $19.78 \mathrm{~b}$ & 30.96 & $44.65 \mathrm{~b}$ \\
\hline \multicolumn{2}{|l|}{ S.L } & $210.3 \mathrm{a}$ & $231.9 \mathrm{a}$ & $253.3 \mathrm{a}$ & $254.6 \mathrm{a}$ & $12.40 \mathrm{a}$ & $23.71 \mathrm{a}$ & 33.02 & $49.80 \mathrm{a}$ \\
\hline \multirow[t]{2}{*}{ V.C.L } & & $194.6 \mathrm{~b}$ & $227.4 \mathrm{a}$ & $258.1 \mathrm{a}$ & $257.2 \mathrm{a}$ & $9.48 \mathrm{~b}$ & $18.48 \mathrm{~b}$ & 29.81 & $38.76 \mathrm{c}$ \\
\hline & \multicolumn{9}{|c|}{ Significance } \\
\hline \multicolumn{2}{|l|}{ Rootstock (R) } & * & * & * & * & ns & * & ${ }^{*}$ & * \\
\hline \multicolumn{2}{|l|}{ Training $(\mathrm{T})$} & $*$ & * & * & ns & * & * & ns & $*$ \\
\hline \multicolumn{2}{|l|}{$\mathrm{R} \times \mathrm{T}$} & ns & ns & * & ${ }^{*}$ & $*$ & $*$ & ns & ns \\
\hline
\end{tabular}

The difference between mean values shown with the same letter is not significant $(\mathrm{p}<0.05)$.

S.B: Spanish bush. S.L.: Steep leader and V.C.L.: Vogel central leader. ns: not significant. ${ }^{*}$ : significant.

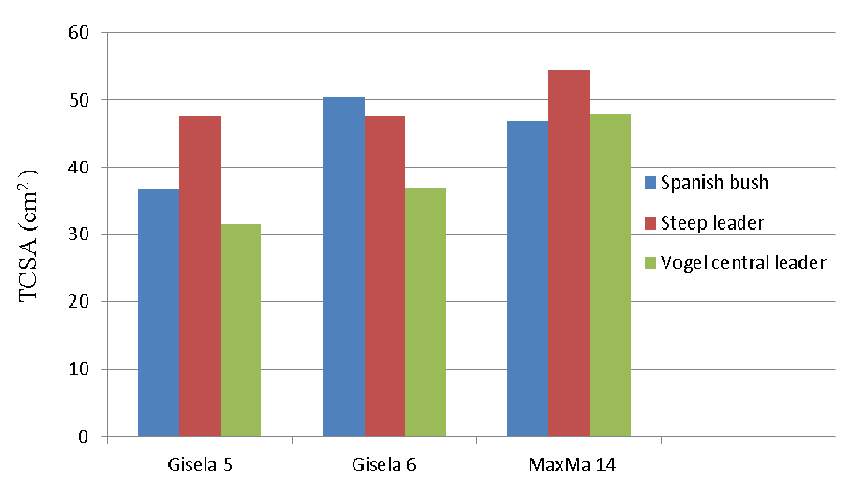

Fig. 1. Influence of rootstock and training system on TCSA (2014)

the used rootstocks 'MaxMa 14 ' is the strongest and 'Gisela 5' is the weakest one. Similar findings were observed in some previous studies (Jimenez et al., 2007; Cantin et al., 2010; Musacchi et al., 2015). Cantin et al. (2010) indicated that trees grafted on 'Gisela 5' had smaller TCSA than those grafted on 'MaxMa 14'. Musacchi et al. (2015) reported that, at the end of fifth year, TCSA of trees grafted on 'Gisela 6 ' rootstock is twice as high as that of the ones grafted on 'Gisela 5 ' rootstock. In this study, in the fourth year after planting, TCSA of trees grafted on 'Gisela 5' was 14\% smaller than of those grafted on 'Gisela 6' rootstocks, and 29\% smaller than of those grafted on 'MaxMa 14 ' rootstock.

Considering training systems, tree height significantly differed between training systems as well. In general, the height of trees was observed to be lower for the ones trained with Spanish bush system. As noted in previous studies (Boucher and Adams, 1995; Tareen and Tareen, 2004; Sitarek and Bartosiewicz, 2012), training systems used in the study have affected tree vigor (TCSA). Researchers indicated that effect of

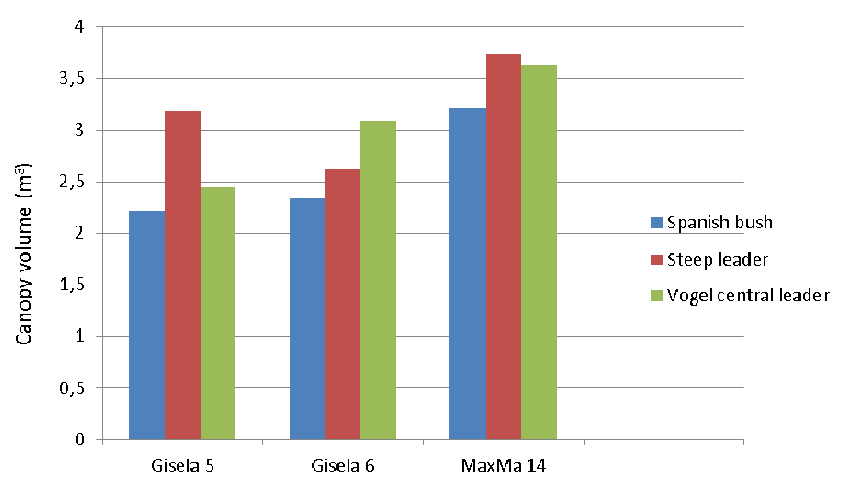

Fig. 2. Influence of rootstock and training system on canopy volume (2014)

training system on TCSA was related to tree density and as tree density increases, TCSA decreases because of the competition between closely planted trees (Musacchi et al., 2015). In this study, even though the planting distances are the same for all three training systems, still in terms of TCSA, significant differences occurred between training systems. In the fourth year (2014), the highest TCSA was measured in Steep leader, followed by Spanish bush, and the lowest in Vogel central leader. As Whiting et al. (2005) stated in their study on different training systems, in the first years, head cutting more branches to establish Steep leader and Spanish bush systems may have increased the number of vegetative meristems and ultimately promoted greater trunk expansion in these systems. The effects of interaction of rootstock and training system on tree height and TCSA showed difference depending on year (Table 1).

During the four years of the trial the trees grafted on 'MaxMa 14' rootstocks had larger canopy volume than those grafted on 'Gisela' rootstocks (Fig. 2). In the first three years, 
Table 2. Influence of rootstock and training system on vegetative growth: canopy volume

\begin{tabular}{|c|c|c|c|c|c|}
\hline \multirow{2}{*}{ Rootstock } & \multirow{2}{*}{$\begin{array}{c}\text { Training } \\
\text { system }\end{array}$} & \multicolumn{4}{|c|}{ Canopy volume $\left(\mathrm{m}^{3}\right)$} \\
\hline & & 2011 & 2012 & 2013 & 2014 \\
\hline \multirow{3}{*}{ 'Gisela 5' } & S.B & 0.27 & 1.09 & $1.62 \mathrm{a}$ & $2.22 \mathrm{~b}$ \\
\hline & S.L & 0.36 & 1.43 & $1.66 \mathrm{a}$ & $3.18 \mathrm{a}$ \\
\hline & V.C.L & 0.25 & 1.34 & $1.56 \mathrm{a}$ & $2.45 \mathrm{~b}$ \\
\hline \multirow{3}{*}{ 'Gisela 6' } & S.B & 0.27 & 1.45 & $1.67 \mathrm{a}$ & $2.33 \mathrm{~b}$ \\
\hline & S.L & 0.22 & 1.39 & $1.61 \mathrm{a}$ & $2.62 \mathrm{ab}$ \\
\hline & V.C.L & 0.17 & 1.71 & $1.93 \mathrm{a}$ & $3.09 \mathrm{a}$ \\
\hline \multirow{3}{*}{ 'MaxMa 14' } & S.B & 0.51 & 1.98 & $2.49 \mathrm{~b}$ & $3.22 \mathrm{~b}$ \\
\hline & S.L & 0.65 & 2.54 & $3.13 \mathrm{a}$ & $3.73 \mathrm{a}$ \\
\hline & V.C.L & 0.54 & 2.47 & $2.68 \mathrm{ab}$ & $3.63 \mathrm{a}$ \\
\hline Rootstock & & \multicolumn{4}{|c|}{ Rootstock average } \\
\hline 'Gisela 5’ & & $0.29 \mathrm{~b}$ & $1.29 \mathrm{~b}$ & $1.61 \mathrm{~b}$ & $2.62 \mathrm{~b}$ \\
\hline 'Gisela 6’' & & $0.22 \mathrm{~b}$ & $1.51 \mathrm{~b}$ & $1.74 \mathrm{~b}$ & $2.68 \mathrm{~b}$ \\
\hline 'MaxMa 14' & & $0.57 \mathrm{a}$ & $2.33 \mathrm{a}$ & $2.77 \mathrm{a}$ & $3.53 \mathrm{a}$ \\
\hline Training system & & \multicolumn{4}{|c|}{ Training system average } \\
\hline S.B & & 0.35 & 1.51 & 1.93 & $2.59 \mathrm{~b}$ \\
\hline S.L & & 0.41 & 1.79 & 2.13 & $3.18 \mathrm{a}$ \\
\hline \multirow[t]{2}{*}{ V.C.L } & & 0.32 & 1.84 & 2.06 & $3.06 \mathrm{a}$ \\
\hline & & \multicolumn{4}{|c|}{ Significance } \\
\hline Rootstock (R) & & * & * & * & * \\
\hline Training $(\mathrm{T})$ & & ns & ns & $\mathrm{ns}$ & $*$ \\
\hline $\mathrm{R} \times \mathrm{T}$ & & ns & $\mathrm{ns}$ & $*$ & * \\
\hline
\end{tabular}

Table 3. Influence of rootstock and training system on yield and fruit weight

\begin{tabular}{|c|c|c|c|c|c|c|c|}
\hline \multirow[t]{2}{*}{ Rootstock } & \multirow{2}{*}{$\begin{array}{l}\text { Training } \\
\text { System }\end{array}$} & \multicolumn{2}{|c|}{$\begin{array}{c}\text { Fruit } \\
\text { weight }(\mathrm{g})\end{array}$} & \multicolumn{2}{|c|}{$\begin{array}{c}\text { Yield } \\
(\mathrm{kg} / \text { tree })\end{array}$} & \multirow{2}{*}{$\begin{array}{c}\text { Cumulative } \\
\text { yield } \\
\left(\mathrm{kg} \mathrm{tree}^{-1}\right)\end{array}$} & \multirow{2}{*}{$\begin{array}{c}\begin{array}{c}\text { Yield } \\
\text { efficiency }\end{array} \\
\left(\mathrm{kg} \mathrm{cm}^{-2}\right)\end{array}$} \\
\hline & & 2013 & 2014 & 2013 & 2014 & & \\
\hline \multirow{3}{*}{ 'Gisela 5' } & S.B & $5.76 \mathrm{a}$ & $5.28 \mathrm{a}$ & $2.7 \mathrm{ab}$ & $10.1 \mathrm{a}$ & $12.8 \mathrm{ab}$ & $0.35 \mathrm{ab}$ \\
\hline & S.L & $5.86 \mathrm{a}$ & $5.19 \mathrm{a}$ & $2.8 \mathrm{a}$ & $10.7 \mathrm{a}$ & $13.5 \mathrm{a}$ & $0.28 \mathrm{~b}$ \\
\hline & V.C.L & $5.96 \mathrm{a}$ & $5.36 \mathrm{a}$ & $2.6 \mathrm{~b}$ & $9.4 \mathrm{a}$ & $12.0 \mathrm{~b}$ & $0.38 \mathrm{a}$ \\
\hline \multirow{3}{*}{ 'Gisela 6' } & S.B & $6.20 \mathrm{a}$ & $6.10 \mathrm{a}$ & $3.0 \mathrm{a}$ & $11.8 \mathrm{~b}$ & $14.8 \mathrm{~b}$ & $0.29 \mathrm{~b}$ \\
\hline & S.L & $5.70 \mathrm{~b}$ & $6.54 \mathrm{a}$ & $2.2 \mathrm{c}$ & $10.4 \mathrm{~b}$ & $12.6 \mathrm{c}$ & $0.27 \mathrm{~b}$ \\
\hline & V.C.L & $5.70 \mathrm{~b}$ & $5.35 \mathrm{~b}$ & $2.6 \mathrm{~b}$ & $14.4 \mathrm{a}$ & $17.0 \mathrm{a}$ & $0.46 \mathrm{a}$ \\
\hline \multirow{3}{*}{ 'MaxMa 14' } & S.B & $7.16 \mathrm{a}$ & $6.29 \mathrm{a}$ & $1.7 \mathrm{~b}$ & $13.5 \mathrm{a}$ & $15.2 \mathrm{a}$ & $0.32 \mathrm{a}$ \\
\hline & S.L & $6.80 \mathrm{a}$ & $6.46 \mathrm{a}$ & $1.8 \mathrm{~b}$ & $13.0 \mathrm{a}$ & $14.8 \mathrm{a}$ & $0.27 \mathrm{a}$ \\
\hline & V.C.L & $6.73 \mathrm{a}$ & $6.01 \mathrm{a}$ & $2.2 \mathrm{a}$ & $13.3 \mathrm{a}$ & $15.5 \mathrm{a}$ & $0.32 \mathrm{a}$ \\
\hline Rootstock & \multicolumn{7}{|c|}{ Rootstock average } \\
\hline 'Gisela 5' & & $5.86 \mathrm{~b}$ & $5.28 \mathrm{~b}$ & $2.7 \mathrm{a}$ & $10.1 \mathrm{c}$ & $12.8 \mathrm{~b}$ & 0.33 \\
\hline 'Gisela 6' & & $5.86 \mathrm{~b}$ & $6.00 \mathrm{a}$ & $2.6 \mathrm{a}$ & $12.2 \mathrm{~b}$ & $14.8 \mathrm{a}$ & 0.33 \\
\hline 'MaxMa 14' & & $6.90 \mathrm{a}$ & $6.25 \mathrm{a}$ & $1.9 \mathrm{~b}$ & $13.2 \mathrm{a}$ & $15.1 \mathrm{a}$ & 0.31 \\
\hline Training system & \multicolumn{7}{|c|}{ Training system average } \\
\hline S.B & & 6.37 & 5.89 & 2.5 & $11.7 \mathrm{~b}$ & 14.2 & $0.32 \mathrm{ab}$ \\
\hline S.L & & 6.12 & 6.06 & 2.6 & $11.4 \mathrm{~b}$ & 14.1 & $0.28 \mathrm{~b}$ \\
\hline \multirow[t]{2}{*}{ V.C.L } & & 6.13 & 5.57 & 2.5 & $12.4 \mathrm{a}$ & 15.1 & $0.39 \mathrm{a}$ \\
\hline & \multicolumn{7}{|c|}{ Significance } \\
\hline Rootstock (R) & & * & * & * & & * & $\mathrm{ns}$ \\
\hline Training $(T)$ & & $\mathrm{ns}$ & ns & ns & & ns & * \\
\hline $\mathrm{R} \times \mathrm{T}$ & & * & * & * & & * & * \\
\hline
\end{tabular}

canopy volume did not differ among different systems. However, in the last year, it was observed that the canopy volume of the trees trained as Spanish bush system was smaller than of those trained as Steep leader and Vogel central leader systems. The interaction of rootstock and training system for the canopy volume was not significant in the first two years, but significant in the last two years (Table 2).

Facteau et al. (1996) who studied with different training systems and rootstocks stated that interaction of rootstock and training system plays an important role in yield. Similarly, in this study, a significant interaction is detected between rootstocks and training systems for yield. In 2013, while the highest yield per tree was obtained from Steep leader system for 'Gisela 5', it was observed from Spanish bush system for 'Gisela 6 and Vogel central leader system for 'MaxMa 14' rootstock. In 2014, there were not any significant differences in yield per tree among training systems for 'Gisela 5' and 'MaxMa 14'. On the other hand, for 'Gisela 6', Vogel central leader had the highest yield among three systems. This shows that the performance of rootstock might change depending on training system choice, or vice versa. Regardless of training systems, when rootstock means are compared, in 2013, trees grafted on 'Gisela 5' and 
Table 4. Influence of rootstock and training system on fruit quality: acidity, soluble solid content (SSC) and fruit firmness

\begin{tabular}{|c|c|c|c|c|c|c|c|c|c|}
\hline \multirow[t]{2}{*}{ Rootstock } & \multirow{2}{*}{$\begin{array}{l}\text { Training } \\
\text { System }\end{array}$} & \multicolumn{2}{|c|}{ Acidity (\%) } & \multicolumn{2}{|c|}{ SSC (\%) } & \multicolumn{2}{|c|}{ Hue angle } & \multicolumn{2}{|c|}{$\begin{array}{l}\text { Firmness } \\
\left(\mathrm{N} \mathrm{mm}^{-1}\right)\end{array}$} \\
\hline & & 2013 & 2014 & 2013 & 2014 & 2013 & 2014 & 2013 & 2014 \\
\hline \multirow{3}{*}{ 'Gisela 5' } & S.B & 0.77 & 0.59 & 14.1 & 12.3 & 33.58 & 27.71 & 3.29 & 3.13 \\
\hline & S.L & 0.77 & 0.69 & 13.7 & 12.4 & 33.63 & 31.18 & 3.25 & 3.16 \\
\hline & V.C.L & 0.71 & 0.62 & 13.6 & 11.8 & 32.32 & 30.61 & 3.16 & 3.14 \\
\hline \multirow{3}{*}{ 'Gisela 6' } & S.B & 0.74 & 0.81 & 13.7 & 14.7 & 32.08 & 25.62 & 3.14 & 3.33 \\
\hline & S.L & 0.72 & 0.71 & 13.7 & 13.8 & 33.87 & 28.68 & 3.13 & 3.16 \\
\hline & V.C.L & 0.65 & 0.61 & 14.1 & 12.6 & 32.56 & 26.3 & 3.25 & 3.14 \\
\hline \multirow{3}{*}{ 'MaxMa 14' } & S.B & 0.69 & 0.77 & 14.6 & 14.7 & 32.34 & 30.91 & 2.98 & 3.35 \\
\hline & S.L & 0.65 & 0.71 & 14.1 & 13.8 & 32.57 & 25.58 & 2.95 & 3.06 \\
\hline & V.C.L & 0.65 & 0.75 & 13.2 & 13.9 & 36.57 & 31.21 & 3.11 & 3.37 \\
\hline \multicolumn{2}{|l|}{ Rootstock } & \multicolumn{8}{|c|}{ Rootstock average } \\
\hline 'Gisela 5' & & 0.75 & 0.63 & 13.8 & 12.2 & 31.18 & 29.83 & 3.23 & 3,14 \\
\hline 'Gisela 6' & & 0.71 & 0.71 & 13.8 & 13.7 & 32.84 & 26.87 & 3.17 & 3.21 \\
\hline 'MaxMa 14' & & 0.66 & 0.74 & 14.1 & 14.1 & 33.83 & 29.23 & 3.03 & 3.26 \\
\hline \multicolumn{4}{|c|}{ Training system } & \multicolumn{4}{|c|}{ Training system average } & & \\
\hline S.B & & 0.73 & 0.72 & 14.1 & 13.9 & 32.67 & 28.08 & 3.14 & 3.27 \\
\hline S.L & & 0.71 & 0.71 & 13.8 & 13.3 & 33.36 & 28.48 & 3.11 & 3.13 \\
\hline \multirow[t]{2}{*}{ V.C.L } & & 0.67 & 0.66 & 13.6 & 12.8 & 33.82 & 29.37 & 3.17 & 3.18 \\
\hline & & \multicolumn{8}{|c|}{ Significance } \\
\hline \multicolumn{2}{|l|}{ Rootstock (R) } & ns & ns & ns & $\mathrm{ns}$ & ns & ns & ns & ns \\
\hline \multicolumn{2}{|l|}{ Training $(\mathrm{T})$} & ns & ns & ns & ns & ns & ns & ns & ns \\
\hline \multicolumn{2}{|l|}{$\mathrm{R} \times \mathrm{T}$} & ns & ns & ns & ns & ns & ns & ns & ns \\
\hline
\end{tabular}

The difference between mean values shown with the same letter is not significant $(p<0.05)$.

S.B.: Spanish bush. S.L.: Steep leader and V.C.L.: Vogel central leader. ns: not significant.

'Gisela 6 rootstocks had higher yield per tree than those grafted on 'MaxMa 14' rootstocks. In 2014, on the other hand, the highest yield per tree was achieved by 'MaxMa 14 ' and the lowest by 'Gisela 5' rootstock. Regardless of rootstocks, when training system means are compared, in 2013, no significant differences between training systems were found. In 2014, on the other hand, the yield per tree of Vogel central leader system was higher than the other two (Table 3). When cumulative yield over two years was evaluated, Steep leader had higher total yield than Vogel central leader systems for 'Gisela 5'. All three training systems resulted in similar cumulative yield with 'MaxMa 14' rootstocks. In terms of cumulative yield, differences between the training systems were more distinctive for 'Gisela 6 ' rootstock. For 'Gisela 6', the highest cumulative yield was obtained from Vogel central leader, the lowest Steep leader training systems. It has been reported that the tree structure is developed using little pruning in Vogel central leader, resulting in a very precocious system (Long, 2003). In this study, while this feature of Vogel central leader system has been clearly observed on 'Gisela 6', it has not been observed on 'MaxMa 14'.

Yield efficiency is a significant criterion that describes the performance of rootstock and training system. For 'Gisela 6, the yield efficiency of Vogel central leader has been found to be distinctively higher than the other two systems. On the other hand, the fruit weight of Vogel central leader was lower than Steep leader and Spanish bush. This result seems to be in line with the findings of Whiting et al. (2005) who indicated the negative correlation between fruit weight and yield efficiency.

For 'Gisela 5' and 'MaxMa 14' rootstocks, no significant differences in average fruit weights were detected between training systems in both trial years. On the other hand, in 2013, for 'Gisela 6', the fruit weight was higher in Spanish bush system compared to Vogel central leader and Steep leader systems, and in 2014, the Vogel central leader training system had the lowest fruit weight among the three training systems
(Table 3). Regardless of training systems, when rootstock means are evaluated, in both years, fruit weights of the trees grafted on 'Gisela 5' rootstocks were lower than of the ones grafted on 'MaxMa 14'. In 2013, there was no significant difference between 'Gisela 5 ' and 'Gisela 6 ' with respect to fruit weights. In 2014, it was seen that 'Gisela 6 ' had higher fruit weight than 'Gisela 5' (Table 3). it has been observed that 'Gisela 5' rootstock is prone to generate smaller fruits. Similar result was reported in some previous studies (Gonçalves et al., 2005; Cantin et al., 2010). Since the trees grafted on 'Gisela 5' were smaller, the yield per tree of this rootstock was lower than of the other two. Similar results are reported in some previously conducted studies (Whiting et al., 2005; Cantin et al., 2010).

There was not determined a significant effect of the rootstock, the training system and the rootstock-training system interaction on acidity, soluble solid content (SSC), fruit firmness and hue angle (Table 4).

\section{Conclusions}

According to the data in the early years, 'Gisela 6 ' and 'MaxMa 14' showed better performance, with higher yield per tree and fruit weight, than 'Gisela 5'. On the other hand, although the yield per tree is low on 'Gisela 5', the advantage of this rootstock such as more density planting, low harvest and pruning costs should be taken into consideration. In addition, it has been seen that the performance of training systems might change depending on used rootstock. In this study, for 'Gisela 6, Vogel central leader system was appeared more advantages. Further research about effect of rootstock and training systems on yield, fruit quality and production economics would be helpful for developing appropriate sweet cherry orchard system recommendations. 


\section{References}

Anonymous (2014). Agriculture statistics. Retrieved 2016 April 2 from htp://www.tuik.gov.tr.

Başkaya Z (2011). The Geographical foundations of cherry farming in Turkey. Eastern Geographical Review 26:45-71.

Boucher WD, Adams G (1995). Influence of orchard production system and cultivar on early productivity of sweet cherry (Prunus avium): effects on tree growth and fruit production and quality. Animal Production Science 35(6):781-787.

Cantin CM, Pinochet J, Gogorcena Y, Moreno MA (2010). Growth, yield and fruit quality of 'Van' and 'Stark Hardy Giant' sweet cherry cultivars as influenced by grafting on different rootstocks. Scientia Horticulturae 123:329-335.

Çerçinli Öz F, Bal T (2016). Ihracatçı açısından Isparta ili kiraz ihracatının analizi [Analysis of cherry exports of Isparta province]. MKÜ Ziraat Fakültesi Dergisi21:71-82.

Facteau, TJ, Chestnut NE, Rowe KE (1996). Tree, fruit size and yield of 'Bing' sweet cherry as influenced by rootstock, replant area, and training system. Scientia Horticulturae 67:13-26.

Fajt N, Folini L, Bassi G, Siegler H(2009). Lapins on ten cherry rootstocks in the Alpeadria Region. $6^{\text {th }}$ International Cherry Symposium, 15-19 November, Renaca-Vina del Mar, Chile.

Gjamovski V, Kiprijanovski M, Arsov T (2016). Evaluation of some cherry varieties grafted on Gisela 5 rootstock. Turkish Journal of Agriculture andForestry 40:737-745.

Gonçalves B, Moutinho-Pereira J, Santos A, Silva AP, Bacelar E, Correia C, Rosa E (2005). Scion-rootstock interaction affects the physiology and fruit quality of sweet cherry. Tree Physiology 26:93-104.

Jimenez S, Pinochet J, Gogorcena Y, Betrán JA, Moreno MA (2007). Influence of different vigour cherry rootstocks on leaves and shoots mineral composition. Scientia Horticulturae 112:73-79.

Lanauskas J, Uselis N, Kviklys D, Kviklienė N, Buskienè L (2012). Rootstock effect on the performance of sweet cherry cv. Lapins. Horticultural Science (Prague) 39:55-60.
Lauri PE, Claverie J (2005). Sweet cherry training to improve fruit size and quality. An overview of some recent concepts and practical aspects. Acta Horticulturae 667:361-366.

Long LE (2003). Cherry training systems: Selection and Development. PNW 543. Oregon State University, Corvallis, OR

Mert C, Soylu A (2007). Possible cause of low fruit set in the sweet cherry cultivar 0900 Ziraat. Canadian Journal of Plant Science 87(3):593-594.

Musacchi S, Gagiardi F, Serra S (2015). New training systems for highdensity planting of sweet cherry. Horticultural Science (Prague) 50:5967.

Radunic M, Jazbec A, Pecina M, Cosic T, Pavicic N (2011). Growth and yield of the sweet cherry (Prunus avium L.) as affected by training system. African Journal of Biotechnology 10(24):4901-4906.

Robinson TL (2005). Developments in high density sweet cherry pruning and training systems around the world. Acta Horticulturae 667:269272.

Sitarek M, Bartosiewicz B (2012). Influence of five clonal rootstocks on the growth, productivity and fruit quality of 'Sylvia' and 'Karina' sweet cherry trees.Journal of Fruit and Ornamental Plant Research 20:5-10.

Tareen MJ, Tareen MN (2004). Effect of rootstocks on 'Bing' cherry grown in Balochistan (Pakistan). International Journal of Agriculture and Biology 6:565-567.

Whiting MD, Lang G, Ophardt D (2005). Rootstock and training system affect sweet cherry growth, yield, and fruit quality. HortScience 40(3):582-586.

Zahn FG (1992). Sind engere Pflanzabstande auch beim Steinobst moglich? [Are closer planting distances also possible with Steinobst?]. Obstbau 9:430-438. 